\title{
Research on the Influence of Commercial System Reform and Enterprise Development
}

\author{
Ping Luo \\ College of Economics, Jinan University, Guangzhou, China \\ Email: 15521264684@163.com
}

How to cite this paper: Luo, P. (2018) Research on the Influence of Commercial System Reform and Enterprise Development. Modern Economy, 9, 988-1001. https://doi.org/10.4236/me.2018.95063

Received: April 10, 2018

Accepted: May 13, 2018

Published: May 16, 2018

Copyright (C) 2018 by author and Scientific Research Publishing Inc. This work is licensed under the Creative Commons Attribution International License (CC BY 4.0).

http://creativecommons.org/licenses/by/4.0/

\begin{abstract}
This paper takes the reform of local commercial system as the basic point, combines the economic data of various provinces and cities in China, adopts the double difference method, and comprehensively inspects the influence of the commercial system reform on the development of the company. The research shows that the establishment of the commercial system reform has significantly improved the level of development of the company, and after a series of robustness tests, the conclusion is still valid; however, the policy effect varies greatly with the regional distribution. Specifically, the net effect of reforming the commercial system in the western region is higher than that in the central region. The net effect of reforming the commercial system in the central region is higher than that in the eastern region, that is, there are more obvious regional differences. From the perspective of the impact mechanism, the reform of the commercial system has reduced the enterprise's transaction costs, simplified the links of the commercial system, promoted the growth of the number of enterprises above designated size, and promoted the development of the enterprise. The research results of this paper show that China should continue to deepen the reform of the commercial system, optimize the commercial approval environment, increase support for the reform of the central and western regions, promote the collaborative cooperation of the commercial examination and approval departments, reduce the institutional transaction costs, and stimulate market vitality.
\end{abstract}

\section{Keywords}

Commercial System Reform, Administrative Approval, Enterprise

Development

\section{Introduction}

The commercial system is an important part of China's socialist market econo- 
my system, and it is an important pre-control method for modern state management and economic affairs. However, with the Chinese economy entering the new normal of development, and the commercial system lacking effective norms, the problems that have always existed in the commercial system have become more and more prominent, and some have become institutional obstacles to the development of the enterprise. Therefore, we need to reform the commercial registration system.

However, since the reform of the commercial system is to be carried out, then a basic question is before us. Can the reform of the commercial system promote the development of enterprises? If it can promote the growth of market players, how much will the growth rate increase? Still further, the reform of the commercial system is through what kind of way to influence the development of the company? At present, few scholars have studied this issue.

At present, there are few literatures studying this issue. There are two main reasons. One is the theoretical level. In theory, there are two very different hypotheses about the influence of the reform of the commercial system on the development of the enterprise. One is the public interest hypothesis, and the other is the public choice hypothesis. The public interest assumes that government administrative regulations, including the commercial system, will help resolve market failures, make up for market deficiencies, promote the rational and effective allocation of resources, and raise the level of social welfare. Therefore, under the public interest hypothesis, the reform of the commercial system may not necessarily promote the development of the enterprise. The hypothesis of public choice, the hypothesis believes that government administrative controls, including the reform of the commercial system, will disrupt the market order. For example, in order to protect the monopolistic profits of enterprises, the government may artificially set strict entry thresholds to hinder the entry of new enterprises. In order to maintain its monopoly status, incumbents continue to obtain monopoly status, bribing relevant officials and causing rent-seeking. Another reason is that it is not easy to identify the impact of the reform of the business system on the development of an enterprise in an empirical strategy. The data is also not easily accessible.

Based on the "quasi-natural experiment" of commercial system reform, this paper takes the reform of the commercial system in cities across the country as a case, and empirically tests the impact of reform of the commercial system on the development of the company. The implementation of the registered capital subscription system, "first follow-up permit," multiple certificates, and electronic information registration are the core of the reform of the commercial system. Based on this, this article through the relevant official business center of the reform of the commercial system, this article manually collected information on the reform of the commercial system in 23 provinces and 294 regions across the country, and searched on the official website of the government's commercial system reform and the website of the Bureau of Industry and Commerce. Such 
as the "capital subscription system," "first according to later licenses," "three certificates into one", "five certificates into one" or "multiple certificates into one", if there are some key words in the commercial system reform, this article reasonably believes that the district has implemented the reform of the commercial system. The specific data includes the following: 1) Does the prefecture-level city implement a registered capital subscription system; 2) The time for the implementation of the reform of the commercial system; 3) Does it promote the integration of multiple certificates; 4) Does the implementation of the first license system follow?

This paper uses the number of industrial enterprises above designated size to measure the progress of enterprise development, and uses the Double Differential Method (DID) to study the impact of the reform of the business system on the development of the enterprise. The empirical results show that compared with the 2009-2016 data, the number of companies above designated size has increased significantly in prefecture-level cities where business system reforms have been carried out compared with prefecture-level cities that have not implemented commercial system reforms. Further research shows that the net effect of reforming the commercial system in the central and western regions is higher than that in the eastern region, that is, there is a clear regional difference. This may be due to a large number of institutional and policy explorations and breakthroughs in the eastern region before the reform of the commercial system. Therefore, the effect of the implementation of the reform of the commercial system is not as significant as that of the central and western regions; In the areas of enterprise development and reform of the commercial system, the rate of enterprise development is still significantly improved. Finally, this paper makes a preliminary discussion on the influence mechanism of the reform of the commercial system on the development of the enterprise.

The research framework of this paper is as follows: The first chapter: Introduction includes the background and significance of the reform of the commercial system. Chapter 2: Literature Review. This section discusses relevant literature on the reform of the commercial system. The third chapter: model setting. This section includes model settings and sources of data. Chapter 4: Empirical Analysis. This section empirically analyzes the impact of the reform of the commercial system on the development of the company. Chapter 5: Conclusion.

\section{Literature Review}

In the existing studies, the institutional factors that affect the development of an enterprise can be roughly divided into three categories: the national institutional environment, the market competition environment, and the enterprise's own management mechanism [1] [2]. The reform of the commercial system is a powerful measure to optimize the development environment of enterprises at the national institutional level. At the same time, the decline of institutional transaction costs brought about by institutional reforms will affect market competition 
[3]. Therefore, this section mainly sorts out the literature from the previous two levels.

\subsection{National System and Business Development}

The institutional environment that affects the development of enterprises at the national level mainly includes the administrative examination and approval environment, the legal environment for intellectual property rights and investor protection, and the regulatory environment for the improvement of financial markets.

The administrative approval environment is crucial to the development of the company. A good administrative approval environment will help reduce the institutional transaction costs in the production and transaction process. Promoting corporate development and innovation activities major adjustments have taken place in China's economic structure and economic development has entered a new normal. To advance the structural reform on the supply side, China's economy has shifted from a high-speed growth phase to a high-quality development phase. There are still many unfavorable factors that hinder the development of enterprises in the administrative approval environment, which is highlighted by the commercial system in the economic field. Administrative approval reform promotes economic growth by reducing the transaction costs of market participants [4]. Administrative examination and approval can suppress social costs and have a certain role in promoting China's economic development. After practice tests, China's gradual approval reform has promoted economic growth, and its microscopic mechanism has reduced the transaction costs of enterprises [5]. The administrative examination and approval reform can reduce the enterprise's institutional cost, which is not only beneficial to the establishment of a new company, but also beneficial to the growth of the incumbent company. The company's entry rate based on the criticality of scale has been significantly improved. The micro-mechanism is the realization of cross-department coordination, which facilitates the entry of new companies and the development of incumbents [6].

The granting of intellectual property rights can ensure that an enterprise has an exclusive monopoly of the market for a period of time and thus obtains a monopoly profit, encouraging the company to expand its business scope; and when the protection of property rights of a country is insufficient, the new company will rush in, counterfeit products, imitations and piracy will intensify [7]. It will disrupt the normal market order. Cause market failure, which will hinder the expansion of the scale of the enterprise and the overall development; investor protection affects the innovation ability of the entire country by affecting the degree of difficulty for the enterprise to obtain innovation; government regulation will be significant Reducing the entrepreneurial probability of individuals is not conducive to business development [8].

The influence of administrative approval environment on enterprise innova- 
tion cannot be ignored either. A good administrative approval environment will help reduce the input costs of enterprises in the production and innovation process and promote the development of enterprises [9]. However, at the stage of economic development, it has entered a new normal, and there are still many unfavorable factors hindering the development of the enterprise in the environment of administrative examination and approval. This is particularly manifested in the existence of administrative examination and approval, especially in the economic field. An important representative of the administrative examination and approval system is the registration of commercial affairs system. The commercial system, also known as business registration, is the legal act of the parties to apply for business affairs to the registration authority of the place where the business office is located, and to review and approve the registration of the business matters in the commercial register in accordance with the contents and procedures stipulated by law. The commercial system is an important manifestation of the national administrative examination and approval system in the economic field [10] [11].

\subsection{Market Competition and Enterprise Development}

A series of studies have shown that relaxing government regulations, lowering barriers to entry-reducing company registration procedures, costs, and time, can help expand the size of companies and the establishment of new companies [12]. As the threshold for market access is reduced, the increase in entrepreneurial behavior will exacerbate market competition. How will the intensified market competition affect the development of the company? However, in the existing literature, economists have not reached consensus on the impact of market competition on business development.

In theory, the government and the market are two basic ways of resource allocation. Among them, the free market provides market participants with the correct information and incentives, and can effectively and reasonably configure limited resources. However, the market itself is incomplete. Problems such as monopoly, spontaneity, blindness, externality, information asymmetry, and lags that prevail in market economic activities will distort market price information, cause market failure, and reduce market Effectiveness. Therefore, effectively preventing market failure has become an important theoretical basis for administrative system reform. The administrative examination and approval includes administrative examination and administrative approval, and there will be administrative examination and approval in all fields of economy and society. The administrative examination and approval system is an important means of managing the country. In the economic field, an important way for the government to manage economic activities is the commercial system. The commercial system is an important manifestation of the national administrative examination and approval system in the economic field.

The public interest theory believes that government regulation can help to 
avoid market economic deficiencies such as spontaneity, blindness, externalities, information asymmetry, and lagging issues, and increase limited resources [13]. Optimize the allocation to improve economic efficiency, social welfare and people's living standards on the other hand. The theory of public choice believes that the government's behavior is not all good-natured. Administrative approval may be a mechanism for creating rents and rents, creating room for rent-seeking [14]. Therefore, administrative examination and approval will result in market failures and inefficient allocation of resources and harm social welfare. Because the government may be captured by companies that maintain interest, and by setting strict regulatory policies to prevent potential market entry, increasing access thresholds to maintain the monopoly of incumbents and monopoly rents

At the micro level, an important mechanism that affects economic performance may be to hinder the entry of potential new companies and the institutional transaction costs of incumbents. This is because government control not only causes market failures, distorts market signals, but also increases the costs needed for entrepreneurial activities. Some authors uses relevant company data from 34 European countries to measure the strength of government administrative regulations with the procedures, fees, and costs required to set up a new company. Research shows that a high degree of government regulation hinders the development of new companies [15]. Established, this phenomenon is particularly evident in those industries that should have higher market entry rates. At the same time, regulation has increased the size of newly established companies and made existing companies grow more slowly, hindering the development of incumbents. Those believe that the impact of government regulation on entrepreneurial activities and corporate development may be related to the quality of government-controlled systems. Using data on the commercial systems of 46 countries from 2005 to 2008, the study found that the procedures needed to start a business are more tedious and Higher minimum capital requirements will significantly reduce the number of new companies entering [16].

However, the impact of the administrative examination and approval system on entrepreneurial activities of enterprises is not all negative. Lusardi focuses on the heterogeneity of the influence of commercial system regulation on entrepreneurial activity. Research based on cross-country data shows that countries with stricter government regulations and In terms of regions, women have more possibilities to start businesses because government regulations hinder the entry of new businesses and hinder employment growth. This makes it more difficult for women in countries and regions where government regulations are more stringent to find satisfactory jobs. This in turn forces women to self-employment. At the same time, stronger government regulations have also weakened the promotion of entrepreneurial activities by social capital and business skills. That is, in countries with stricter regulations, entrepreneurs who are familiar with other entrepreneurs and people with higher business skills have lower probability of entrepreneurship. Strict regulations reduce the expected benefits of entrepre- 
neurial activities for the purpose of pursuing business opportunities.

From a theoretical perspective, on the one hand, the reform of the commercial system has reduced the market access threshold, simplified the procedures for commercial registration, reduced the intensity of administrative approval, and can restrict the promotion of business entry [17]. In the economic system, if there is an excess profit in an industry, it will attract new enterprises, and the reform of the commercial system will reduce market entry barriers, remove the barriers to the establishment of new enterprise systems, and promote the entry of enterprises. Therefore, the reform of the commercial system will lead to a higher rate of entry for new enterprises in the profit industry. With the entry of new enterprises and the total industry profits unchanged, the profit space of the incumbents will be compressed, which intensifies market competition. Too many companies chase less profit, which is not conducive to the growth of the company. On the other hand, the reform of the commercial system has reduced the intensity of administrative examination and approval. The institutional costs of incumbents have decreased and the profits of enterprises have increased, which is conducive to the growth of incumbents [18]. At the theoretical level, the relationship between the reform of the commercial system and the development of the enterprise has not reached a consistent conclusion.

In summary, in the relevant theoretical analysis or empirical test, the establishment of a new company's business registration system and the relationship between entrepreneurship and business development have not reached a unanimous conclusion. In view of this, this paper will use panel data at the prefecture-level city level from 2009 to 2016 to systematically evaluate the impact of the reform of the commercial system on the development of the company and its possible heterogeneity. On the one hand, by constructing a theoretical model, we explore the micro-mechanism of the commercial system's influence on the development behavior of enterprises; on the other hand, we use the relevant government website information and the statistical yearbooks of each province and city to construct an econometric model to test the incentive effect of the reform of the business system on the development of the enterprise. The research in this paper not only focuses on the examination of the development of enterprises, but also makes an in-depth analysis of the influence on different regions. Further analysis of the differences in the influence of the reform of the commercial system on the development of enterprises in different regions can be found: The incentive effect of the business development system for the development of enterprises has significant differences in different regions and there will be heterogeneity.

\section{Research Design}

\subsection{Model Settings}

This paper uses the Dual Difference Method (DID) to assess the impact of the reform of the business system on the number of enterprises above designated size. The basic logic is as follows: 1) Select "proper" prefecture-level cities that 
have not carried out reform of the commercial system as a control group, making the overall economic growth trend approximately the same as that of the experimental group. 2) Calculate the differences in the number of enterprises above designated size in the corresponding jurisdiction within the control group before and after the policy. Under the principle of meeting the consistency of the above-mentioned overall growth trend, this difference also reflects the influence of other factors in the experimental group in addition to the reform of the commercial system on the development of the company. 3) Finally, calculate the differences in the number of enterprises above designated size before and after the reform of the commercial system in the experimental group, and remove the influence of the common factors mentioned above. The net benefit of the reform of the commercial system for the above-scale enterprises can be obtained. That is, the net benefits to the development of the enterprise.

In order to quantitatively examine the impact of the reform of the commercial system on the number of enterprises above designated size and the development of the enterprise, the DID model is specifically set as follows:

$$
y_{i t}=\alpha+\beta_{1} * \text { time }+\beta_{2} * \mathrm{dt}+\beta_{3} * \text { time } * d t+\varepsilon_{i t}
$$

where $y$ represents the number of companies above designated size, $\alpha$ is constant, time period variable, $d t$ dummy variable ( $d t=0$, on behalf of the commercial system before the reform; $d t=1$ represents the reform of the commercial system). In this article, this article innovatively uses the number of companies above the scale as a proxy variable for the size of the company's development and economic growth.

After that, we added other control variables, such as the age of the company, the number of employees, and the share of foreign capital fshare, which continued to return. The explanatory variables were all taken from the previous period, while the explanatory variables were taken from the current period. To help control potential endogenous problems. The model is set as follows:

$$
y_{i t}=\alpha+\beta_{1} * \text { time }+\beta_{2} * \mathrm{dt}+\beta_{3} * \text { time } * d t+\beta * X_{t-1}+\varepsilon_{i t}
$$

where $y$ represents the number of companies above designated size, $\alpha$ is constant, time period variable, $d t$ dummy variable ( $d t=0$, on behalf of the commercial system before the reform; $d t=1$ represents the reform of the commercial system). In this article, this article innovatively uses the number of companies above the scale as a proxy variable for the size of the company's development and economic growth. $X$ represents the control variable, including the proportion of foreign investment (fshare), total population at the end of the year (pop), total tax (tax), gross domestic product (gdp), and fixed asset investment (ifa).

\subsection{Index Construction}

1) The explanatory variable. $Y$ is the proxy variable that describes the innovation, entrepreneurship, and regional economic growth of the company. In the existing research, some scholars use the economic input such as research and development costs or the number of $\mathrm{R} \& \mathrm{D}$ personnel to measure enterprise in- 
novation and development. However, taking into account the availability of $\mathrm{R} \&$ $\mathrm{D}$ investment data, this paper innovatively adopts the number of enterprises above designated size and the scale of the company's assets, the total profit and the number of employees to measure the development of the enterprise.

2) Core explanatory variables-reform of the commercial system. The core of the reform of the commercial system is to streamline the procedures for administrative approval, simplify power administration, reduce market entry barriers, and exercise strict supervision. In other words, the process of the reform of China's commercial system is concentrated in the three aspects of "registered capital subscription system," "first follow-up permit," and "multiple evidence integration." This article innovatively uses these three indicators to measure the reform of the commercial system. This article manually collects information from 32 provinces and 294 prefecture-level cities in the country. Through inquiring about the official website of the reform of the commercial system, if all these three policies are implemented, this paper reasonably believes that the region has undergone reform of the commercial system. Then $\mathrm{dt}=1$, otherwise $\mathrm{dt}=0$

3) Control variables. The selection of $X_{-}$ct mainly refers to Liu et al. (2015), including Inage, Inemployment, Foreign share, Inpopulation, and Intax. This article refers to (Bi Qingmiao and Xu Xianxiang: 2018)the practice of selecting GDP, per capita GDP, investment in fixed assets, the city's administrative level, the geographical location of the city and whether the city is close to the eastern coastal areas.

\subsection{Data Collection}

The main sources of the data in this paper are the following two parts: 1. Statistical Yearbooks of Chinese Provinces and Cities 2009-2016. The statistical object of this paper's data is the number of enterprises above designated size in each level city, the total assets and total profits of the enterprise, and the employees of the company 2, open information query statistics. Statistics of provincial and municipal government departments, registration capital registration system, registration declarations (first and second evidence) and "multiple evidence integration". This article manually collects the official website of the 3294 prefecture-level commercial systems of the country and the government network such as the Bureau of Industry and Commerce. Search keywords "registered capital subscription registration system", "registration declaration (first follow-up certificate)" and "multiple certificates". Information such as the "“" and the specific reform year, if relevant government documents appear these keywords closely related to the reform of the commercial system, this paper believes that the implementation of the reform of the commercial system is based on basic facts.

\section{Empirical Analysis}

\subsection{Analysis of Regression Results}

In theory, the advancement of the reform of the commercial system has, on the 
one hand, reduced the use of non-productive, transactional costs for enterprises to promote the growth of enterprises and increase the number of enterprises above designated size; on the other hand, it has reduced the market entry of enterprises by reducing Entry barriers, increased market competition, and reduced corporate profit margins will inhibit corporate innovation and the expansion of scale and the increase in the number of companies. Therefore, the impact on the number of enterprises above designated size is uncertain.

This paper first uses model (1) and model (2) to empirically study the influence of the reform of commercial system on the number of industrial enterprises above designated size.

In Table 1, column (1) is a baseline test without any control variables, and (2) - (5) are cases where control variables are gradually added. From column (1), we

Table 1. Effect of the reform of the commercial system on the number of enterprises above designated size.

\begin{tabular}{|c|c|c|c|c|c|c|}
\hline $\ln y$ & (1) & (2) & (3) & (4) & (5) & (6) \\
\hline \multirow[t]{2}{*}{ time } & $-82.92^{\star * *}$ & $-64.96^{\star \star \star}$ & $-76.57^{\star * *}$ & $-73.46^{\star * *}$ & $-53.97^{* * *}$ & $-57.95^{\star \star \star}$ \\
\hline & $(-2.74)$ & $(-3.35)$ & $(-5.764)$ & $(-2.75)$ & $(-3.57)$ & $(-3.74)$ \\
\hline \multirow[t]{2}{*}{$\mathrm{dt}$} & -43.21 & -43.42 & -47.28 & -38.53 & -73.67 & -24.59 \\
\hline & $(-0.30)$ & $(-0.358)$ & $(-0.86)$ & $(-0.70)$ & $(-0.93)$ & $(-1.57)$ \\
\hline \multirow[t]{2}{*}{ time* dt } & $246.18^{\star \star \star}$ & $143.53^{\star * *}$ & $140.37^{\star \star}$ & $134.53^{\star \star}$ & $132.43^{*}$ & $104.18^{\star}$ \\
\hline & $(3.88)$ & $(4.28)$ & $(2.26)$ & $(2.18)$ & $(1.89)$ & $(1.88)$ \\
\hline \multirow[t]{2}{*}{$\operatorname{lnfs}$} & & $8.93^{* *}$ & $8.76^{\star *}$ & $6.52^{\star *}$ & $5.32^{* *}$ & $4.79^{\star *}$ \\
\hline & & $(2.62)$ & $(2.37)$ & $(2.47)$ & (2.98) & $(2.63)$ \\
\hline \multirow[t]{2}{*}{ lnpop } & & & $5.60^{* * *}$ & $6.01^{* * *}$ & $8.63^{* *}$ & $7.31^{* *}$ \\
\hline & & & $(3.27)$ & $(3.44)$ & $(2.20)$ & $(2.12)$ \\
\hline \multirow[t]{2}{*}{$\ln \operatorname{tax}$} & & & & 1.12 & 9.65 & 2.18 \\
\hline & & & & $(1.47)$ & $(1.28)$ & $(1.35)$ \\
\hline \multirow[t]{2}{*}{ lngdp } & & & & & -3.55 & -1.44 \\
\hline & & & & & $(-0.16)$ & $(-0.13)$ \\
\hline \multirow[t]{2}{*}{$\operatorname{lnifa}$} & & & & & & -2.29 \\
\hline & & & & & & $(-0.34)$ \\
\hline \multirow[t]{2}{*}{ _cons } & $-9.87^{\star * *}$ & $-9.82^{* * *}$ & $-7.26^{* * *}$ & $-9.24^{\star * *}$ & $-13.35^{\star * \star}$ & $-29.79^{\star * *}$ \\
\hline & $(-6.79)$ & $(-3.65)$ & $(-3.74)$ & $(-3.65)$ & $(-3.88)$ & $(-3.77)$ \\
\hline $\mathrm{N}$ & 1008 & 1008 & 1008 & 1008 & 1008 & 1008 \\
\hline $\begin{array}{c}\text { Urban fixed } \\
\text { effect }\end{array}$ & yes & yes & yes & yes & yes & yes \\
\hline $\begin{array}{c}\text { Fixed year } \\
\text { effect }\end{array}$ & yes & yes & yes & yes & yes & yes \\
\hline $\mathrm{R}^{2}$ & 0.298 & 0.330 & 0.358 & 0.374 & 0.415 & 0.498 \\
\hline
\end{tabular}

Note: The T statistic is in parentheses, ${ }^{*}{ }^{* *}$, and ${ }^{* * *}$ are significant at the levels of $10 \%, 5 \%$, and $1 \%$, respectively. 
can see that when other control variables are not added, that is, only the time variable time, the policy variable $\mathrm{dt}$, and the cross term time $\mathrm{e}^{\star} \mathrm{dt}$ of the two are considered, the coefficient of the time variable time is -82.92 , which is smaller than adding other control variables. The coefficient of the control variable, the coefficient of the cross-time* ${ }^{\star}$ t is 246.18 , and its absolute value is larger than that when other control variables are added. Since our focus is on the net effect of conducting business system reforms, that is, focusing on the coefficient of time ${ }^{\star} \mathrm{dt}$ of the cross terms, it can be generally seen from the regression results in (1) that the reform of the commercial system has positively affected the number of enterprises above designated size, and It is significant at the $1 \%$ level of significance. From column (2), we can see that after adding the control variable of the proportion of foreign capital fs, the coefficient of the time variable time increases from the original -82.92 to -64.96 , and the coefficient of the cross $^{\star}$ time $^{\star} \mathrm{dt}$ is 143.53 , which is reduced, but Still significant at the $1 \%$ level of significance. The coefficient of foreign capital proportion fs is positive, and it is significant at the $5 \%$ significance level. Specifically, when the proportion of foreign capital increases by $1 \%$, it will increase the number of enterprises above designated size by 8.93\%. Columns (3) - (6) are added to the variable in order. At the end of the year, when the total population pop, total tax (tax), GDP, gdp, and fixed asset investment ifa, it can be seen that the time variable, the time coefficient, has changed, and remains the same. Significant at the $1 \%$ level of significance, indicating that the time effect of the reform of the commercial system is more obvious. The coefficient of the cross-time time ${ }^{\star} \mathrm{dt}$ gradually decreased from 140.37 to 104.18 , and remained at least significant at the $10 \%$ significance level. This indicates that although the coefficient of the cross-term time* ${ }^{\star}$ th has changed after adding the control variable, it is still significant. In other words, it shows that the reform of the commercial system has a positive and significant effect on the number of enterprises above designated size. Among them, the total pop population at the end of the period has a positive impact on the number of enterprises above designated size, and is significant at the $5 \%$ level of significance. Specifically, when the total pop population increases by $1 \%$ at the end of the period, it will increase the number of enterprises above designated size by $7.31 \%$. The total tax, tax, gross domestic product (gdp), and fixed-asset investment ifa have positive or negative effects on the number of enterprises above designated size, but they are not significant.

Therefore, this part can basically reach the conclusion that the reform of the commercial system has significantly increased the number of enterprises above designated size and promoted the development of the enterprise.

\subsection{Robustness Test}

In order to test the robustness of the above regression results, we replaced the interpreted variables in model (2) with the emp employees of the above-scale enterprises and re-analyzed them. The results are shown in Table 2. 
Table 2. Robustness test results.

\begin{tabular}{|c|c|c|c|c|}
\hline lnemp & Full sample & East & Central & West \\
\hline \multirow[t]{2}{*}{$\mathrm{du}$} & $25.77^{\star}$ & $30.80^{*}$ & $20.88^{*}$ & $18.28^{*}$ \\
\hline & (1.95) & $(1.88)$ & $(1.89)$ & $(1.93)$ \\
\hline \multirow[t]{2}{*}{$\mathrm{dt}$} & 7.767 & 5.861 & 3.954 & 2.780 \\
\hline & $(0.95)$ & $(0.86)$ & $(0.72)$ & $(1.25)$ \\
\hline \multirow[t]{2}{*}{$\mathrm{du}^{*} \mathrm{dt}$} & $20.14^{* *}$ & $16.99^{* *}$ & $24.83^{\star * *}$ & $26.46^{* * *}$ \\
\hline & (2.58) & $(2.35)$ & $(3.50)$ & $(3.66)$ \\
\hline \multirow[t]{2}{*}{$\operatorname{lnfs}$} & $3.24^{* *}$ & $4.79^{*}$ & $2.07^{*}$ & $1.97^{*}$ \\
\hline & $(2.27)$ & $(1.83)$ & $(1.92)$ & $(1.86)$ \\
\hline \multirow[t]{2}{*}{ lnpop } & $5.12^{* *}$ & $6.26^{* *}$ & $8.50^{\star *}$ & $4.37^{\star}$ \\
\hline & $(2.31)$ & $(2.27)$ & $(2.19)$ & $(1.88)$ \\
\hline \multirow[t]{2}{*}{$\ln \operatorname{tax}$} & $5.43^{\star *}$ & $7.55^{\star *}$ & $4.67^{* *}$ & $1.23^{* *}$ \\
\hline & $(2.50)$ & $(2.62)$ & $(2.79)$ & $(2.37)$ \\
\hline \multirow[t]{2}{*}{ lngdp } & $-16.27^{* *}$ & $-20.13^{\star *}$ & $-20.90^{* *}$ & -10.29 \\
\hline & $(-2.27)$ & $(-2.31)$ & $(-2.41)$ & $(-0.68)$ \\
\hline \multirow[t]{2}{*}{$\operatorname{lnifa}$} & -16.57 & -25.64 & $-19.34^{*}$ & -29.63 \\
\hline & $(-1.70)$ & $(-1.70)$ & $(-1.90)$ & $(-1.70)$ \\
\hline \multirow[t]{2}{*}{ _cons } & $66.82^{* *}$ & $55.24^{* *}$ & $44.61^{\star *}$ & $23.62^{\star *}$ \\
\hline & $(2.33)$ & $(2.28)$ & $(2.17)$ & $(2.19)$ \\
\hline $\mathrm{N}$ & 1008 & 464 & 320 & 224 \\
\hline $\mathrm{R}^{2}$ & 0.481 & 0.527 & 0.482 & 0.504 \\
\hline
\end{tabular}

Note: The T statistic is in parentheses, ${ }^{*},{ }^{* *}$, and ${ }^{* *}$ are significant at the levels of $10 \%, 5 \%$, and $1 \%$, respectively.

The first column in Table 2 shows the regression results for the whole sample, the second column shows the regression results for the eastern region, the third column shows the regression results for the central region, and the fourth column shows the regression results for the western region.

After analyzing the regression results in Table 2, it is easy to see that after replacing the original explanatory variables with the emp employees of the company, the coefficient of the cross terms has changed, but it is still significantly positive, specifically when the full sample is used. The coefficient is 20.14 , which is significant at the $5 \%$ significance level; for the eastern region, the cross item coefficient is 16.99 , which is significant at the $5 \%$ significance level; for the central region, the cross item coefficient is 24.83 , which is significant at $1 \%$. The level of sexuality is significant; for the western region, the cross-term coefficient is 26.46, which is significant at the $1 \%$ level of significance; the comparison can find that after the explanatory variable is replaced with the enterprise's employees, it is replaced by the explanatory variable before it is replaced. The cross-term coefficients of the eastern, central and western regions are gradually 
increasing. This shows that the net effect of reforming the commercial system in the western region is higher than that of the central region. The net effect of reforming the commercial system in the central region is higher than that of the eastern region. Showing more obvious regional differences. Therefore, it can be considered that the above regression results are robust.

\section{Conclusions}

This article uses the double difference method to empirically analyze the impact of the reform of the commercial system on the development of the enterprise. The study found that: overall, the reform of the commercial system has significantly promoted the development of the enterprise and improved the development level of the enterprise. Further research shows that the policy effect of the reform of the commercial system varies greatly depending on the distribution of the regions. Specifically, the net effect of reforming the commercial system in the western region is higher than that in the central region. The net effect of reforming the commercial system in the central region is higher than that in the eastern region, that is, there are more obvious regional differences.

After a series of robustness tests, this conclusion is still valid. From the perspective of the impact mechanism, the reform of the commercial system has significantly reduced the institutional transaction costs of enterprises. On one hand, it has reduced the cost of the company's expenditures and promoted the development of the company; on the other hand, the entry of new companies will intensify market competition and reduce the number of enterprises. The profit space is not conducive to the expansion of the company's scale and overall development. Overall, the reform of the commercial system has promoted the development of the enterprise.

\section{References}

[1] Branstetter, L., Lima, F., Taylor, L.J., et al. (2014) Do Entry Regulations Deter Entrepreneurship and Job Creation? Evidence from Recent Reforms in Portugal. Economic Journal, 124, 805-832. https://doi.org/10.1111/ecoj.12044

[2] Berry, F.S. and Berry, W.D. (1990) State Lottery Adoptions as Policy Innovations: An Event History Analysis. American Political Science Review, 84, 395-415. https://doi.org/10.2307/1963526

[3] Bruhn, M. (2008) License to Sell: The Effect of Business Registration Reform on Entrepreneurial Activity in Mexico. Policy Research Working Paper, 93, 382-386.

[4] Kumar, U. and Mishra, P. (2008) Trade Liberalization and Wage Inequality: Evidence from India. Review of Development Economics, 12, 291-311. https://doi.org/10.1111/j.1467-9361.2007.00388.x

[5] Khandelwal, A.K., Schott, P.K. and Wei, S.J. (2013) Trade Liberalization and Embedded Institutional Reform: Evidence from Chinese Exporters. American Economic Review, 103, 2169-2195. https://doi.org/10.1257/aer.103.6.2169

[6] Bi, Q.M., Chen, X.L. and Xu, X.X. (2018) Administrative Approval and Enterprise Entry. Economic Research, 2, 139-153.

[7] Chen, G. (2015) Regulation and Entrepreneurship-Micro-Evidence from China. 
Management World, 5, 89-99.

[8] Branstetter, L., Lima, F., Taylor, L.J., et al. (2014) Do Entry Regulations Deter Entrepreneurship and Job Creation? Evidence from Recent Reforms in Portugal. Economic Journal, 124, 805-832. https://doi.org/10.1111/ecoj.12044

[9] Blanchflower, D.G. and Oswald, A.J. (1998) What Makes an Entrepreneur? Journal of Labor Economics, 16, 26-60. https://doi.org/10.1086/209881

[10] Haan, J.D. and Sturm, J.E.. (2011) On the Relationship between Economic Freedom and Economic Growth. European Journal of Political Economy, 16, 215-241. https://doi.org/10.1016/S0176-2680(99)00065-8

[11] Abadie. A. and Gardeazabal, J. (2001) The Economic Costs of Conflict: A Case Study of the Basque Country. American Economic Review, 3, 112-132.

[12] Almond, D. et al. (2009) Winter Heating or Clean Air? Unintended Impacts of China's Huai River Policy. American Economic Review, 99, 184-190.

https://doi.org/10.1257/aer.99.2.184

[13] Ouyang, M. and Peng, Y.L. (2013) The Treatment-Effect Estimation: A Case Study of the 2008 Economic Stimulus Package of China. The Journal of Economics, 23, 23-57.

[14] Branstetter, L., Lima, F., Taylor, L.J., et al. (2014) Do Entry Regulations Deter Entrepreneurship and Job Creation? Evidence from Recent Reforms in Portugal. Economic Journal, 124, 805-832. https://doi.org/10.1111/ecoj.12044

[15] Haan, J.D. and Sturm, J.E. (1999) On the Relationship between Economic Freedom and Economic Growth. European Journal of Political Economy, 16, 215-241. https://doi.org/10.1016/S0176-2680(99)00065-8

[16] Djankov, S., Porta, R.L. and Shleifer, A. (2002) The Regulation of Entry. Quarterly Journal of Economics, 117, 1-37. https://doi.org/10.1162/003355302753399436

[17] Djankov, S., Qian, Y., Roland, G., et al. (2006) Who Are China's Entrepreneurs? American Economic Review, 96, 348-352. https://doi.org/10.1257/000282806777212387

[18] Glaeser, E.L., Kerr, S.P. and Kerr, W.R. (2012) Entrepreneurship and Urban Growth: An Empirical Assessment with Historical Mines. Review of Economics and Statistics, 97, 498-520. https://doi.org/10.1162/REST_a_00456 